\title{
Para além das fronteiras nacionais: imagens do americanismo como modelo de vida no ocidente. O Brasil como estudo de caso (1945-1964)*
}

\section{Resumo}

Este artigo procura demonstrar como se deu a globalização de um modelo cultural pautado no modelo estadunidense a partir do pós-45, entendendo a construção do ocidente como resultado de uma disputa por hegemonia dentro de um determinado contexto histórico. Nesse contexto, as imagens ganharam destaque como veículo de contato entre os sujeitos e o mundo que os cerca, ou seja, como um mecanismo de leitura do real. A pesquisa foi feita a partir da análise de imagens disponíveis em revistas de grande circulação no Brasil com pontuais comparações com revistas de circulação hemisférica, tais como a Reader's Digest. Dessa forma, foi possível traçar os discursos imagéticos hegemônicos presentes na imprensa brasileira e disponíveis para subjetivação do público leitor. Conclui-se como o uso das imagens contribuiu para a construção de um modelo de vida e cotidiano hoje chamado de ocidental a partir do americanismo, tomando, para isto, a realidade brasileira como estudo de caso.

Palavras Chave: Américas, cultura Norte Americana, visualização.

Referencia para citar este artículo: M. S. ARRAES, Marcos Alexandre de (2017). "Para além das fronteiras nacionais: imagens do americanismo como modelo de vida no ocidente. O Brasil como estudo de caso (1945-1964)”. En Anuario de Historia Regional y de las Fronteras. 22 (2). pp. 99-119.

Marcos Alexandre de M. S. Arraes: Doutor em História pela Universidade Federal de Santa Catarina com período Sanduíche na University of California, Irvine. Mestre em História Cultural pela Universidade Federal de Santa Catarina, Brasil. Graduação em História pela Universidade Federal de Pernambuco, Brasil. Professor Adjunto A-1 da Universidade Federal do Tocantins, Brasil. Correo electrónico: maarraes@gmail. com. Código ORCID: 0000-0002-8893-6561.

\footnotetext{
* O referido artigo é fruto de pesquisa de doutoramento concluído em 2015 com financiamento das agências CAPES-Brasil e Fulbright Foundation-EUA. Trata-se de parte de um capítulo da tese transformado em artigo exclusivamente para submissão a esta revista.
} 


\title{
Beyond National Borders: Images of Americanism as a Model of Life in the West. Brazil as a Case Study (1945-1964)
}

\begin{abstract}
This article tries to demonstrate how the globalization of a cultural model based on the American model occurred after 1945, understanding the construction of the West as a result of a dispute for hegemony within an specific historical context. In this context, the images gained prominence as a vehicle of contact between the subjects and the world around them, that is, as a mechanism for reading the real. The research was made from the analysis of images available in magazines of great circulation in Brazil with punctual comparisons with magazines of hemispheric circulation, such as Reader's Digest. In this way, it was possible to trace the hegemonic imagery discourses present in the Brazilian press and available for reader's subjectivation. It is concluded that the use of images contributed to the construction of a daily life model based on the Americanism so called Western, taking, for this, the Brazilian reality as a case study.
\end{abstract}

Keywords: Americas, North American Culture, Visualization.

\section{Más allá de las fronteras nacionales: imágenes del americanismo como un modelo de vida en occidente. El Brasil como un estudio de caso (1945-1964)}

\section{Resumen}

En el presente artículo se muestra el desarrollo de la globalización desde un modelo cultural basado en el modelo estadounidense pos-45, tomando la comprensión de la construcción de Occidente como resultado de disputas por la hegemonía dentro de un contexto histórico especifico. En este contexto, las imágenes ganaron la prominencia como un vehículo de enlace entre el sujeto y el mundo que les rodea, o sea, como un mecanismo de lectura de la realidad. La investigación se realizó a partir del análisis de las imágenes disponibles en grandes revistas de circulación en Brasil y ocasionalmente en revistas de circulación hemisférica, tales como el Reader's Digest. Fue posible rastrear los discursos imagéticos hegemónicos presentes en la prensa brasileña y disponible para la subjetividad del público lector. De ello se desprende cómo el uso de imágenes contribuyó a la construcción de un modelo de vida cotidiana que ahora se llama occidental, teniendo, por esto, la realidad brasileña como un estudio de caso.

Palabras clave: Américas, cultura norteamericana, visualización. 


\section{Introdução}

O presente artigo objetiva analisar o uso e importância da visualidade como agente de consolidação do modelo de civilização estadunidense enquanto paradigma para todo o mundo ocidental no pós-Segunda Guerra. Em outras palavras, buscar-se-á entender a globalização do americanismo ${ }^{1}$ na segunda metade do século XX, tendo como ponto de partida a construção de uma comunidade imaginada ${ }^{2}$ a que hoje chamamos de mundo ocidental. Para tanto, utilizarei o Brasil como estudo de caso, onde, como veremos, fezse necessário um amplo esforço de enquadramento e apresentação do americanismo e seus valores centrais a partir de uma série de práticas, às quais às imagens foram produto central.

Antes de mais nada, penso ser necessário definir o que estou entendendo como americanismo. De forma simplista e direta, poder-se-ia defini-lo como um conjunto de práticas culturais relativas aos Estados Unidos da América. Todavia, a simplicidade, nesse caso, pende para uma perigosa generalização que nada explica.

Antonio Gramsci, ao que parece, foi o primeiro pensador a se ater a esse conceito no texto Americanismo e Fordismo, incluso em seu Cadernos do Cárcere, de 1934. Para ele, o termo qualificava um equivalente cultural necessário ao modelo fordista de produção fabril.

Nesse sentido, o americanismo denota um modelo de sociedade, o que implica dizer que ele enquadra não apenas práticas culturais, como também um modelo de produção econômica e reprodução social. Em outras palavras, uma cultura em sentido amplo, englobando tudo aquilo que foi construído e dotado de sentido pelo homem em sua experiência no tempo.

\footnotetext{
${ }^{1}$ Apesar de não se tratar de palavra estrangeira, o termo será utilizado em itálico neste artigo por uma questão política. Acredito que o substantivo América e seus adjetivos correlatos sejam mais amplos que a realidade estadunidense. Contudo, por tratar-se de um conceito já estabelecido na historiografia, optei por utilizá-lo, mas deixando-o em destaque.

${ }^{2}$ A referência aqui é ao conceito desenvolvido por Benedict Anderson, ainda que em contexto e situação distintos. A analogia se faz possível pois, tal como Anderson pensa o conceito de nação, a formação de um bloco hegemônico que partilha de instituições econômicas, militares e culturais, também possui um sentimento de pertença comum que tem raízes em uma construção cultural. Assim, percebo a ideia de Ocidente ou Mundo Ocidental, como uma construção imagética, que não possui organização política, fronteiras definidas ou mesmo uma história comum, mas baseia-se numa partilha de valores, ideais e sentimentos de pertença comuns, ou seja, de uma imagem mental de unidade. Isso não implica dizer que ela seja ilusória ou irreal. Ao contrário, ela se realiza no campo do simbólico e nele constitui subjetividades. Em última instância, para citar Anderson, “[...] ela é imaginada pois, mesmo os membros da mais minúscula nação jamais conhecerão, encontrarão ou sequer ouvirão falar da maioria de seus companheiros, embora todos tenham em mente a imagem viva da comunhão entre eles". Anderson, Benedict. Comunidades imaginadas. Reflexões sobre a origem e a difusão do nacionalismo (São Paulo: Cia das Letras, 2008), p. 32. Cabe ressaltar, no entanto, que tal comunhão não suplanta outras comunidades imaginadas, tais como a nação ou outras existentes dentro dessa mesma comunidade, mas funciona em diálogo e, por vezes, em conflito com estas. Por fim, é preciso dizer que existe uma longa discussão a respeito da construção do Ocidente, desde o período da Antiguidade Clássica e não estou querendo supor uma originalidade dessa construção no período do Pós-Guerra, mas sim, destacar esse período como um marco histórico de transformação na ideia e escopo da imagem do Ocidente, que passa a ser associado aos valores do americanismo.
} 
Para além das fronteiras nacionais: imagens do americanismo como modelo de vida...

Para a ocasião deste artigo, estou considerando como americanismo o projeto civilizador estadunidense esboçado e sucessivamente reelaborado, recortado, reinterpretado, desde a fundação da nação. Um projeto que, à medida que foi sendo estabelecido na prática na conquista das fronteiras do Oeste das treze colônias, passou a ganhar força e ampliar seu escopo de ação, fazendo surgir o Destino Manifesto. As repetidas lapidações que esse esquema recebeu, contudo, não deixaram de lado alguns valores tidos como essenciais e universais, entre eles os ideais de liberdade, democracia e individualidade.

Não estou, com isso, pensando o americanismo enquanto um télos histórico que mira, através de sucessivas progressões, um futuro promissor e positivo. Ao contrário, esse foi um modelo de sociedade que aconteceu historicamente, sendo sucessivamente recolocado e rearranjado dentro de suas historicidades. Foi a história, e exclusivamente dentro dela, que, entre acasos, acertos diplomáticos e outras condições de possibilidade, permitiu que tal projeto se tornasse hegemônico ao longo do século XX e, assim, se universalizasse ${ }^{3}$.

Tal tema é bastante recorrente na historiografia latino-americana desde, ao menos, a década de 60 do século passado. Contudo, boa parte dessas obras faz uso das ideias de dominação, chegando mesmo a comparar as relações dos Estados Unidos com os outros países americanos como uma nova colonização, considerando a presença estadunidense ao sul de suas fronteiras como uma imposição ${ }^{4}$. Não desmerecendo tais trabalhos, que tiveram e têm contribuído para o debate sobre a questão, adoto aqui outra vertente analítica. $\mathrm{Na}$ esteira das renovações nas pesquisas promovidas pela chamada virada cultural, acredito que a cultura é um organismo vivo, dinâmico e circular, não cabendo, portanto, o termo imposição. Semanticamente, imposição significa ação de obrigar a aceitar e, portanto, possui um caráter limitador da agência de quem recebe a ação. Supor que o Brasil sofreu um imposição cultural estadunidense, não só implica dizer que elementos culturais podem ser determinados a alguém, esvaziando o princípio dialógico e histórico da cultura, como também implica uma relação onde apenas um dos sujeitos age, sendo uma relação passiva. Sendo assim, o presente artigo procura contribuir na atualização do debate historiográfico a respeito do tema, tratando as relações entre os Estados Unidos com o continente americano como uma relação de força, muitas vezes desigual, mas que implicou em ações e reações tanto de aceitação quanto de recusa e resistência. Isso implica dizer que os países ao sul do Rio Bravo não apenas foram sujeitos passivos, vítimas de uma Teoria da Dependência, mas agiram, tanto aceitando determinados aspectos políticos, econômicos e culturais

\footnotetext{
${ }^{3}$ Note-se que utilizei aqui o conceito gramsciano de hegemonia, o que implica dizer que tal modelo, contudo, não era único e sofreu resistências políticas e culturais. Contudo, fez-se presente como o principal e mais divulgado pelos meios oficiais da imprensa nacional e hemisférica.

${ }^{4}$ Dentre tais trabalhos, mas não limitados a estes: Falivene Alves, Júlia. A invasão cultural norte-americana (São Paulo: Ed. Moderna, 1988); Bandeira, Moniz. Presença dos Estados Unidos no Brasil: dois séculos de história (Rio de Janeiro: Civilização Brasileira, 1978); Donghi, T. H. Historia Contemporánea de América Latina (Madrid: Alianza Editorial, 1969); Dorfman, Ariel e Mattelart, Armand. Para leer al Pato Donald (Buenos Aires: Siglo XXI Editores, 2003); Chomsky, Noam. O que o Tio Sam realmente quer (Brasília: Ed. UnB, 1999).
} 
advindos de fora, quanto recusando e defendendo suas posições em determinados momentos. Acredito ser importante essa transformação para que possamos superar as explicações do determinismo histórico, que imputa ao outro a responsabilidade pelo nosso destino; é urgente que possamos reavaliar as relações de classe e força interna aos nossos países e que entendamos que essas articulações se fazem não como uma imposição, mas como diálogos ressoantes em esferas hegemônicas para que possamos dar voz e vez para as possibilidades contra-hegemônicas. Nos limites deste texto, contudo, irei apenas iniciar a primeira etapa do trabalho, deixando para um próximo texto a discussão sobre as resistências ao modelo aqui discutido.

Retomando a análise, um momento, em especial, merece destaque para o caso em estudo: a atuação do Office of the Coordinator of Inter American Affairs (OCIAA) nos anos 40 no Brasil ${ }^{5}$, pois, concordando com Tota, foi a partir da atuação desse órgão que se estruturou efetivamente " $[$...] o americanismo, entendido aqui como uma ideologia programática, em que o sufixo -ismo tinha se transformado num poderoso armamento intencional, com o claro objetivo de suplantar outros-ismos, autóctones ou não" .

É nesse momento que os brasileiros começam a familiarizar-se com o discurso americanista e o estilo de vida cotidiano proposto por ele: o American way of life. No bojo desse discurso estavam presentes diversos elementos valorativos, tais como o ideal de democracia, o progresso, o tradicionalismo, o trabalho, a liberdade -muitos desses condensados na ideia de self made man- que seriam bombardeados através de diferentes instrumentos de produção discursiva. Cada uma dessas ideias estava conectada e imbricada uma à outra, de forma a construir uma ideologia bem acabada e pronta a ser exportada. No entanto, no caso do Brasil, elas tiveram diferentes recepções e apropriações de acordo com o momento e a realidade vividos pelo país.

É, portanto, partindo dessa acepção que irei trabalhar o conceito de americanismo para adequá-lo ao momento em análise. Estou levando em consideração o imaginário do que era o American way of life no Brasil pós-1945. Ou melhor, o que os principais órgãos de imprensa divulgavam como sendo o padrão de vida estadunidense com vistas, quase sempre, a tornar esse modelo um paradigma a ser seguido pela sociedade brasileira. Esses discursos, no entanto, não eram meras fabricações ilusórias ou equivocadas, mas sim uma seleção de aspectos hegemônicos presentes naquela cultura e que se queriam tornar universais.

Comecemos, então, por uma imagem.

\footnotetext{
${ }^{5}$ Órgão criado em 1940 pelo governo F. D. Roosevelt com o objetivo de, através de um esforço conjunto de produção cultural, estreitar os laços entre as nações do continente Americano dentro da lógica da Política da Boa Vizinhança.

${ }^{6}$ Tota, Antônio Pedro. Imperialismo Sedutor: a americanização do Brasil na época da Segunda Guerra (São Paulo: Cia das Letras, 2000), p 19.
} 
Para além das fronteiras nacionais: imagens do americanismo como modelo de vida...

Imagem 1. Fotografia, tirada em Williams, Arizona.

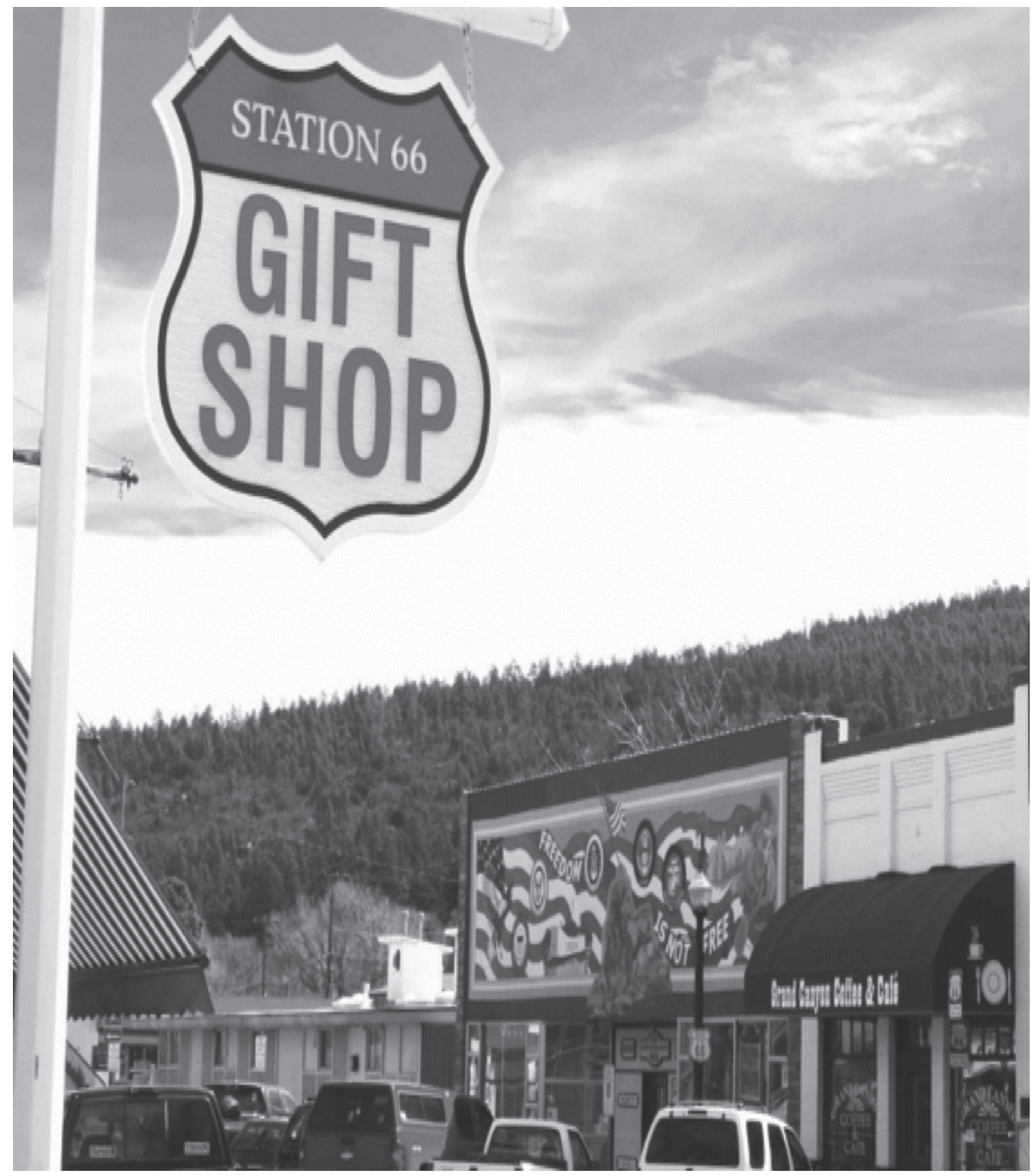

Fonte: acervo pessoal

Esta fotografia, tirada em Williams, Arizona, resume os principais valores representados pelo americanismo. Ao topo de uma das casas comerciais do centro da cidade há uma imensa pictografia com a bandeira estadunidense em toda a sua extensão. Ao centro, a representação da famosa fotografia tirada na batalha de Iwo Jima na Segunda Grande Guerra e que, desde então, passou a significar o esforço estadunidense na busca por paz, democracia e liberdade em todo o mundo. Essa imagem traz soldados ao topo de um cume, lutando contra o vento e se expondo a possíveis inimigos para ali fincar o símbolo máximo da nação, que, naquele momento, representava todo o mundo livre. No canto esquerdo, logo abaixo das estrelas da 
bandeira, a águia estadunidense, representação máxima da liberdade naquele país? Ao longo de toda a extensão, escudos e figuras de todas as forças armadas dos Estados Unidos. Finalmente, à direita vê-se um homem idoso e um garoto olhando como em um misto de contemplação e resignação a um cemitério cheio de lápides. Lê-se ainda a mensagem: Freedom is not Free.

Imagem 2. Detalhe da imagem anterior

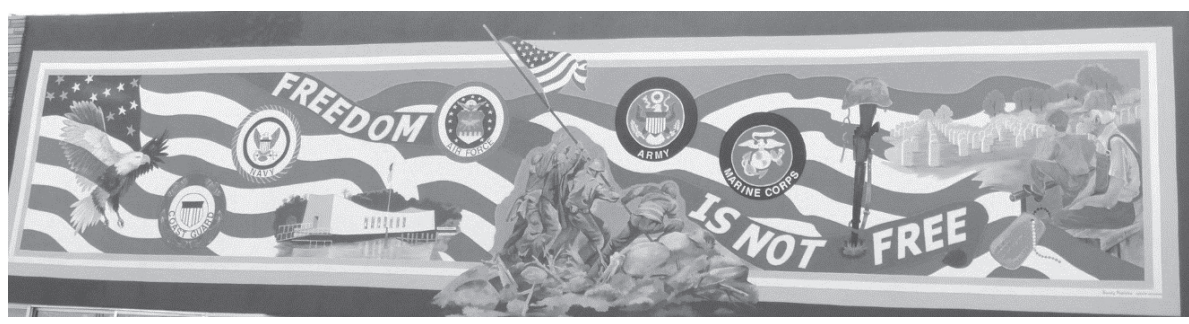

Fonte: acervo pessoal

No primeiro plano, uma placa sinaliza: Station 66 Gift Shop. Mais uma vez, o discurso é claro e direto: a liberdade é um valor máximo e onipresente. Mas não é gratuita, há um preço a ser pago, deve ser conquistada e preservada. É preciso atenção e força. As armas garantem essa liberdade e poder. Apenas assim a democracia e os valores ocidentais estariam garantidos. A ironia com a comercialização não foi em vão. Na democracia liberal instituída naquele país, parte central do considerado melhor projeto de civilização até então existente, tudo tinha um preço e precisava ser conquistado, lutado, suado. Nada pode vir de graça ou por iniciativa do Estado patriarcal. Numa sociedade assim estabelecida, afinal, que representante melhor da democracia, liberdade e igualdade que o consumo (para os padrões estadunidenses)?

'A Coke is a Coke', Andy Warhol once wrote, for example, 'and no amount of money can get you a better Coke than the one the bum on the corner is drinking' (Warhol, 1975:101). We are asked to understand, here, that American democratic ideology is embeded in the machinery of mass consumption. Alternatively, it is also the case that the capitalist model of mass consumption is impossible to achieve without some forme of liberal democracy to produce and protect the 'freedom' to buy the same thing as everyone else: needless to say, Warhol's aphorism also requires the structural presence of the bum on the corner in order to celebrate the 'classlessness' of both the product and the act of consumption. But the real democracy posited in Warhol's pictures of Coke bottles, and in the advertising images of which he drew, is one of objects rather than social relations ${ }^{8}$.

\footnotetext{
${ }^{7}$ Para maiores informações a respeito da águia enquanto representação da liberdade no imaginário estadunidense: Hackett Fischer, David. Liberty and Freedom: a visual history of America's founding ideas (Oxford Univesity Press, 2005).

${ }^{8}$ Holloway, David e Beck, John. American Visual Cultures (London, New York: Continuum, 2005), p. 2.
} 
Para além das fronteiras nacionais: imagens do americanismo como modelo de vida...

O consumo torna-se essencial para a cultura e sociedade estadunidense ao final da guerra. Naquele momento, não se tratava de uma urgência meramente econômica. Eram as bases da existência mesmo da nação que estavam em xeque, era o próprio americanismo que precisava ser defendido. E isso não vinha de graça. Diante das responsabilidades de potência vitoriosa e líder do bloco ocidental, era necessário fazer frente ao modelo soviético que se impunha do lado oriental. Cabia, portanto, mostrar as razões para o seu excepcionalismo, conforme afirmou Tocqueville.

Para muitos, o ato de consumir continha em si os valores basilares que precisavam ser defendidos e alastrados pelo mundo livre ocidental ${ }^{9}$. Não estou assumindo que essa prática, por si só, define de forma inequívoca a sociedade e cultura estadunidenses ${ }^{10}$. O objetivo é analisar os discursos que buscaram enunciar o ato de consumir como um valor universal a ser defendido a qualquer custo, pois acreditava-se estar relacionado às liberdades individuais e à democracia social. Importa atentar para essa questão, uma vez que foram esses mesmos discursos incorporados pela mídia hegemônica no Brasil e enunciados como o paradigma máximo de determinados setores sociais do país, especialmente nos anos 50 e $60^{11}$.

Com o raiar da Guerra Fria, o esforço dos Estados Unidos seria direcionado para ativar toda uma estrutura enunciativa para a construção da ideia de mundo livre ocidental, no sentido de demonstrar o que esse modo de vida tinha de diferente. Era preciso convencer os europeus e também as Américas de que there is no way like the American way. Mais que isso, convencer de que não havia diferenças entre o American way e o Western way como um todo, que havia uma irmandade de interesses e objetivos, visões e práticas cotidianas comuns que fundavam essa comunidade imaginada.

[...] the American state acknowledged the special place advertising ocupied in the conduct of foreign affairs. Whereas other countries employed propaganda in pursuit of their interests, by means of heavy-handed government sloganeering, America emplyed publicity in pursuit of its global mission, using essentially private means, the skillfully nuanced counsel of its mass-communication industries. And whereas other countries propagated ideology, the American nation professed ideals ${ }^{12}$.

\footnotetext{
${ }^{9}$ Essa não era a única visão sobre o consumo na sociedade estadunidense. Como aponta Glickman, a questão era bastante ambígua e controversa, havendo os que defendiam o ato de consumir com os valores individuais e a saúde da economia, mas também os que apontavam os males da desigualdade econômicosocial. Glickman, Lawrence B. Consumer society in American history: A Reader (Cornell University Press, 1999).

${ }^{10}$ Existem diversas discussões a respeito de se seria a vida simples a verdadeira base do espírito estadunidense ou, ainda, este estaria mais relacionado à vida material e prosperidade iniciada pelos primeiros fundadores da nação. Para mais a esse respeito: Glickman, Lawrence B., Op. Cit.

${ }^{11} \mathrm{Tal}$ assunto é estudado no livro Figueiredo, Camargo Moraes, Anna Cristina. “A Liberdade é uma calça velha azul e desbotada", em Publicidade, Cultura de Consumo e Comportamento Político no Brasil (19541964) (São Paulo: Hucitec, 1998).

${ }^{12}$ De Grazia, Victoria. Irresistible empire: America's advance through $20^{\text {th }}$ century Europe (Cambridge, Massachusetts: Harvard University Press, 2005), p. 239.
} 
Foi nesse sentido que um grande esforço propagandístico foi realizado para construir a ideia de comunidade atlântica a partir do Plano Marshall e da OTAN ${ }^{13}$. Ao mesmo tempo, diversas outras políticas eram desenvolvidas por órgãos do governo dos Estados Unidos para divulgar os valores essenciais da nação e, logo, da comunidade ocidental que buscavam forjar.

Procurando mesclar os esforços do governo no sentido de divulgar o American way of life como grande paradigma mundial com a força dos produtos enquanto transformadores de hábitos que os artífices da diplomacia estadunidense conseguiram um acordo cultural entre o seu país e a URSS. Entre as ações deste acordo estava a realização de feiras de exibição de produções artísticas, moda, hábitos cotidianos e, em especial, produtos industrializados em ambos os países, como serve de exemplo a realização da Feira Internacional de Moscou, ou American National Exhibition, como ficou conhecido nos Estados Unidos o evento ocorrido no final da década de 1950.

No escopo dessas ações e com objetivos similares, ainda na mesma década, a CIA, com suporte do Pentágono e outras agências estatais e privadas, desenvolveu a Militant Liberty Campaign, uma ação conjunta para inserir o tema da liberdade em alguns filmes produzidos pelos estúdios de Hollywood de forma velada ${ }^{14}$. Assim, não apenas a liberdade, em suas mais diversas formas, era divulgada, mas também a democracia era vendida como um valor universal.

Da mesma forma que esses valores eram válidos para os cidadãos estadunidenses, eram também válidos para todo o mundo. Tratava-se de valores aceitos e desejados por todos. Era nisso que acreditavam e isso que queriam fazer que todos acreditassem através de pronunciamentos, conferências e propagandas diversas.

Contudo, a maior arma do americanismo em sua cruzada universalista seria a cultura de consumo, vendendo seus ideais de forma mesclada com os produtos, afinal, “[... a publicidade, como o literato conservador francês Georges Duhamel censurou, vendia não apenas os bens, mas também os adjetivos para falar sobre eles. A capacidade de mudar os termos da conversação sobre os bens básicos da vida era um poder imenso" $" 15$. E o poder não estava apenas na propaganda, mas nos produtos em si. "Máquinas de costura, ferros elétricos, máquinas de lavar e utensílios de cozinha não eram ninharias; eles alteravam profundamente os modos de viver, especialmente para as mulheres"16.

\footnotetext{
${ }^{13}$ Defendo que o Plano Marshall foi o braço econômico e a OTAN o braço político e militar da construção de uma comunidade imaginada popularizada como Mundo Ocidental. Além dessas iniciativas culturais também divulgavam uma cultura partilhada e comum entre todas as nações desse grande bloco, dando corpo e substância à comunidade. Parte dessa discussão está diluída neste artigo.

${ }^{14}$ Para mais informações sobre a Militant Liberty Campaign e outras iniciativas da chamada Guerra Fria Cultural: Stonor Saunders, Frances. The Cultural Cold War: The CIA and the world of arts and letters (New York: The New Press, 2000).

${ }^{15}$ Gracia, Victoria de. Op Cit., p. 238.

${ }^{16} \mathrm{Ibid}, \mathrm{p} .133$.
} 
Para além das fronteiras nacionais: imagens do americanismo como modelo de vida...

Essa característica que os objetos possuem de transformar hábitos e mesmo subjetividades foi discutira pelo historiador francês Daniel Roche, que propõe uma releitura do consumo a partir dos objetos e dos valores culturais que eles adquirem na sociedade. Esses valores dizem respeito à transformação do natural, do objeto concreto em si, em algo cultural, usado na intermediação da relação homem / natureza, como, por exemplo, a pedra nas sociedades ditas pré-históricas. Em outras palavras, aos objetos é dada uma propriedade cultural histórica, que possibilita aos indivíduos transformar a sua experiência ${ }^{17}$.

Nesse sentido, Roche traz à tona uma análise do consumo como uma forma do homem se relacionar com o mundo. A partir daquilo que se produz e se consome, as pessoas passam a perceber e experienciar esse mundo de uma forma diferenciada. Aspectos da vida cotidiana passam a ser modificados a partir da interação de determinados objetos com a vivência do real. As ideias de frio e calor, tempo, espaço, por exemplo, mudam de acordo com novas invenções tecnológicas e os diferentes usos dos objetos fazem as pessoas verem e perceberem o mundo de formas diferentes ${ }^{18}$.

Os produtos, portanto, na sociedade de consumo, com a participação ativa da propaganda possibilitada por uma cultura que dá agência às imagens, uma cultura em que a existência é visualizada, adquirem novos significados. A sua utilidade não reside apenas no seu valor de uso ou troca, como queriam alguns críticos marxistas, mas na sua capacidade de proporcionar novas sensações, possibilitar novas experiências. As mercadorias passam a ter voz na construção de identidades sociais e nos processos de subjetivação.

This is what media scholar Stuart Ewen has termed the commodity self, the idea that our selves, indeed our subjectivities, are mediated and constructed in part through our consumption and use of commodities. Clothing, music, cosmetic products, and cars, among other things, are commodities which people use to present their identities to those around them ${ }^{19}$.

Desse modo, difundir os seus produtos industrializados por todo o ocidente não era apenas uma demanda econômica para os Estados Unidos, mas também um dever civilizador. Fazia parte da releitura do seu Destino Manifesto a partir da conjuntura inaugurada no pós-guerra, onde a experiência é cada vez mais mediada por imagens, com as quais a publicidade e o consumo irão se mesclar para oferecer sonhos, prazeres e imagens. Logo, ao vender suas mercadorias, as indústrias estadunidenses estavam prestando um serviço ao americanismo, pois, ao adquirir um desses produtos, os consumidores não estavam apenas comprando o seu valor de uso ou a materialidade do objeto, mas, mais que isso, também um uma cultura, um modo de vida.

\footnotetext{
${ }^{17}$ Roche, Daniel. História das Coisas Banais: o nascimento do consumo nas sociedades do século XVII ao XIX (Rio de Janeiro: Rocco, 2000), p. 19.

${ }^{18}$ Ibid., p 20.

${ }^{19}$ Sturken, Marita e Cartwright, Lisa. The practices of looking. An introduction to Visual Culture (Oxford University Press, 2001), p. 198.
} 
Um modo de vida cinemático, pois em constante movimento, cinematográfico, pois vivido nas e pelas imagens, sinestésico, pois abusa da dinâmica dos sentidos na elaboração das percepções. Uma sociedade do espetáculo. Esse é o título da crítica situacionista de Guy Debord a essa realidade cultural, em que as estruturas simbólicas da sociedade são transformadas para dar passagem ao delírio das imagens. Para Debord, a existência nesse momento foi enfraquecida devido à industrialização da cultura, que fragmenta a vida real. Os indivíduos, aí, perdem sua agência e passam a consumir, sem perceber, as imagens de tudo aquilo que lhes falta na sua vida real. Uma existência vazia, ilusória, onde só existe o espetáculo. Mas este não se resume a um conjunto de imagens, mas uma "relação social entre pessoas mediatizadas por imagens", diz o francês, e nele, a mercadoria desempenha um papel de destaque: "O espetáculo é o momento em que a mercadoria ocupou totalmente a vida social. Não apenas a relação com a mercadoria é visível, mas não se consegue ver nada além dela: o mundo que se vê é o seu mundo" ${ }^{20}$.

Debord percebe bem as transformações processadas no ocidente com o final da segunda guerra mundial. A sua sociedade do espetáculo reúne o que venho discutindo como sendo a emergência de uma nova ordem do olhar que traz as imagens para frente do palco para desempenhar um protagonismo na experiência cotidiana, onde o consumo, integrado à visualidade, também ganha novo dinamismo e importância, proporcionando aos indivíduos formas diferenciadas de subjetivação e identidade. Nesse mundo, a realidade e representação passam a ocupar o mesmo lugar no espaço, deixando de habitar lugares distintos no regime de verdade.

Mas é justamente aqui que a reflexão de Debord perde sua força. Tal como Baudrillard e também alguns filósofos da Escola de Frankfurt, Debord interpreta o regime visual contemporâneo como refém de uma indústria cultural que tanto cria como atende a um público massificado, que, por sua vez, não consegue mais distinguir entre o mundo real e o mundo do simulacro. Para muitos desses pensadores, essa integração da visualidade com a indústria de massa é uma forma de dominação capitalista, que mantém as pessoas reféns de ilusões, podendo, assim, ser facilmente manipuladas.

Ora, devo insistir, ao separar e hierarquizar realidade e representação, imagem e matéria, esses autores não apenas deslocam a experiência contemporânea de sua historicidade como também retiram a agência do expectador. A preponderância das imagens nesse tempo não é um mecanismo maquínico, que surge por conta própria, como que de forma maniqueísta e planejada, mas sim algo dinâmico e realizado pelo próprio expectador; é um processo que atende às necessidades, anseios, desejos e expectativas dos indivíduos na contemporaneidade. Nessa relação com o visual, o indivíduo/expectador tira seu poder de ação e delega ação às imagens. Portanto, a indústria de massas não funda culturas homogêneas; cabe ao indivíduo o seu poder de transitar por seus produtos de forma a potencializar a sua experiência. Isso não quer dizer que não haja uma cultura hegemônica, mas, ao contrário, que dentro

${ }^{20}$ Debord, Guy. A Sociedade do Espetáculo (Rio de Janeiro: Contraponto, 1997), p. 30. 
Para além das fronteiras nacionais: imagens do americanismo como modelo de vida...

dela existe a ação do indivíduo, não sendo ele manipulado de forma passiva. Todo indivíduo/expectador é um agente ativo de sua experiência. ${ }^{21}$

\section{"O que é bom para os Estados Unidos, é bom para o Brasil"}

A célebre frase acima foi pronunciada por Juracy de Magalhães, primeiro embaixador brasileiro do regime ditatorial iniciado em 1964, e é bastante representativa do momento em questão. Com o golpe militar daquele ano, o Brasil anunciava para o mundo a sua opção definitiva pelo bloco ocidental na conjuntura da Guerra Fria, e, portanto, a aceitação do modelo americanista, com seus valores e, principalmente, sua ordem visual.

O processo sedutor que havia convencido muitos brasileiros durante a atuação do OCIAA na década de 1940, ganha nova roupagem no período do pós-guerra. Mesmo sem contar mais com uma estrutura organizada e direcionada a atrair o público brasileiro para o seu modus vivendi, a diplomacia estadunidense teria, todavia, aliados de peso na cultura de consumo e no regime visual.

É claro que nada disso era uma completa novidade. O relacionamento de intensa proximidade entre as duas nações durante a segunda guerra mundial já havia conseguido consolidar os Estados Unidos enquanto um paradigma de liberdade, democracia e modernidade. Inclusive a partir de mecanismos visuais.

A ação interativa do cinema fixava no imaginário brasileiro a imagem dos heróis americanos. O processo de americanização pelo cinema efetivava-se no mercado. Nos objetos anunciados na imprensa, seria possível identificar uma relação perfeita entre a noção concreta do próprio objeto e sua representação. $\mathrm{O}$ americanismo no significado e no significante. Anúncios ou reportagens pareciam muitas vezes reproduzir, tanto na propaganda ilustrada como no próprio texto, cenas de filmes ${ }^{22}$.

Entretanto, as transformações ocorridas naquele país após as duas bombas atômicas e os acordos de paz e, principalmente com o início da Guerra Fria, tiveram grandes reflexos políticos e, especialmente culturais. Esses reflexos se fizeram sentir em todo o mundo ocidental. No Brasil não seria diferente. As novas demandas estadunidenses chegariam em território nacional e seriam reinterpretadas e readaptadas ao cenário local a partir dos desejos e necessidades do momento.

\footnotetext{
${ }^{21}$ Estou considerando o conceito de agência aqui de acordo com Anthony Giddens, para quem os indivíduos possuem a capacidade de viver a experiência social de forma subjetiva, concebendo formas de enfrentar a vida, mesmo quando sofrendo diferentes formas de violência institucional. Assim, como já explicitado anteriormente neste artigo, acredito que cada espectador é um sujeito único, que age sobre os discursos hegemônicos podendo endossá-los, reinterpreta-los, recusá-los ou mesmo ignorá-los. Para mais a respeito do conceito de agência vide: Giddens, Anthony. A Constituição da Sociedade (Rio de Janeiro: Martins Fontes, 2003). Sobre espectador/espectadorismo: Sturken, Marita e Cartwright, Lisa, Op. Cit.

${ }^{22}$ Tota, A. Pedro, Op Cit., p. 132.
} 
Qual seria, então a leitura brasileira do American way of life nesse momento? Iniciemos, tal como na seção anterior, com uma imagem.

Imagem 3. Fotografia. Faz parte de uma reportagem da edição de 17 de maio de 1952 de Manchete intitulada "Descobridor de Estrelas".

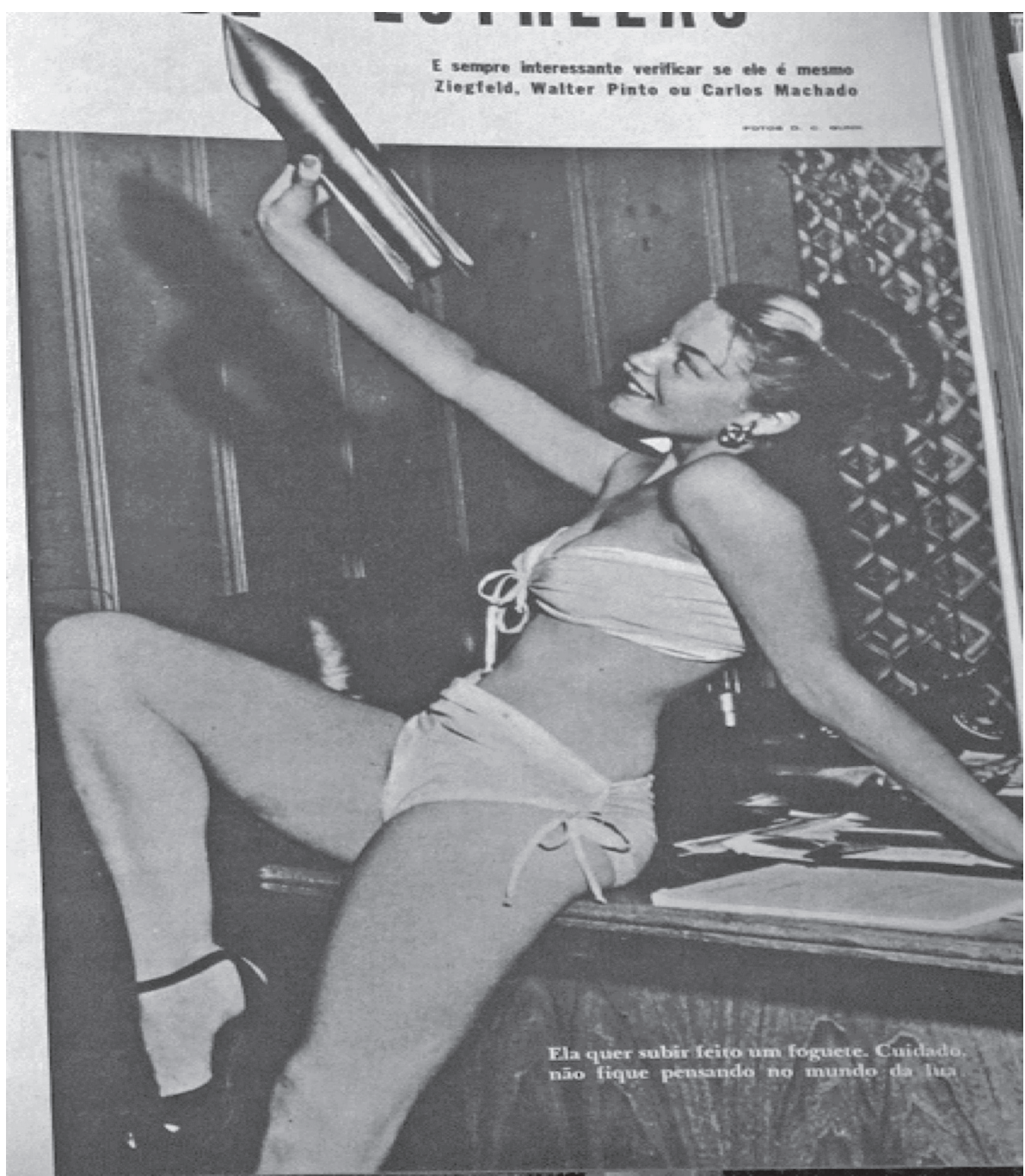

Fonte: Manchete, 17 de maio de 1952.

A fotografia da Imagem 3 faz parte de uma reportagem da edição de 17 de maio de 1952 de Manchete intitulada "Descobridor de Estrelas", que procurava apresentar os perigos dos falsos caçadores de talentos para as garotas aspirantes ao mundo das estrelas no Rio de Janeiro e em outras cidades brasileiras. A escolha da revista pela imagem da a atriz estadunidense Sheree Bessire é significativa. Ela está sentada, 
Para além das fronteiras nacionais: imagens do americanismo como modelo de vida...

trajando um biquíni, com uma das mãos apoiada sob a mesa e a outra segurando acima da cabeça um protótipo de foguete. Seu olhar está voltado para o alto, fixo na mesma direção que o foguete em sua mão. Seu semblante sereno e sorridente; um sorriso alegre e confiante. Mas que confiança seria essa? Para onde mira tão fixamente a modelo?

Aqui podemos ver uma perfeita representação do ideal americanista em sua interpretação hegemônica no Brasil. O uso da modelo estadunidense já deixa entrever um ideal estético, o paradigma do belo: mulheres brancas, loiras, com porte corporal médio e um corte e penteado muito semelhante ao das pinup girls estadunidenses ${ }^{23}$. Este ideal podia ser visto na maior parte das fotografias de modelos nas principais revistas em circulação, nas campanhas de publicidade e, especialmente, no imaginário masculino do período.

Aliás, o público masculino brasileiro foi rapidamente cooptado pela beleza das atrizes e modelos estadunidenses, como narra a cronista Laura Suarez:

[...] Encontrei-a hoje à tarde e impressionou-me seu abatimento moral. Investiguei. Por incrível que pareça, Clarinha havia brigado com o marido por causa da Joan Crawford.

'Não é que eu tenha ciúmes de uma estrela de cinema. Também não sou tão desfrutável assim. Mas é que às vezes a gente transborda. [...] Não é todo dia que a gente está disposta a receber pontapés'. Eu estranhei: 'Mas Carlos, tão boa pessoa, que foi isso?'. Ela ergueu os ombros carnudos. 'Maneira de falar. Mas esses homens são de amargar. Todos, minha filha. Não se salva um. A gente se mata por eles de amanhã à noite e o prêmio é esse: ingratidão. Pensa que reconhecem alguma coisa? Nunca. Sacrifício para eles é obrigação. Uns miseráveis'. Eu pedi que ela deixasse de generalizar e falasse do Carlos. 'Mas é dele mesmo que estou falando. Imagine que ontem nós fomos ao cinema. A tal da Crawford. Na saída, o que é que você pensa que ele me disse, com os olhos todos derreados?' ‘Aquilo é que é Mulher'. Cínico! Se isso é coisa que se diga na minha cara! [...] Desaforo. Fiquei furiosa, é claro. Respondi: 'Não diga. E o que você tem em casa o que é?' Ele nem se deu por achado. Estava com uma cara de pateta, levou dez minutos para atravessar a rua. 'Que corpo, hein?' Eu concordei: 'é, para quem gosta de osso.' Ele ficou meio ofendido: 'Osso? Que absurdo. Ela tem um corpo formidável. Isso é mágoa sua.' Você acredita? Mágoa. Ah, não lhe disse mais uma palavra. Nem hoje de manhã. E quando ele chegar a noite vai ser a mesma coisa. Estúpidos ${ }^{24}$.

\footnotetext{
${ }^{23} \mathrm{O}$ termo pin-up significa algo a ser exposto, colado na parede. A sua associação a garotas surgiu no contexto da Segunda Guerra Mundial, quando algumas modelos, entre elas Betty Grable, passaram a posar para fotografias sensuais destinadas aos soldados em combate. Essas fotos seriam exportas nas paredes dos alojamentos dos soldados. Após a popularização, o termo passou a denotar uma estética específica, com determinadas poses, cortes de cabelo e estilo de vestir. A questão da sensualidade, no entanto, também está associada às pinups, e, portanto, não é incomum o uso do termo para imagens e modelos anteriores ao período aqui descrito.

${ }^{24}$ Suarez, Laura. "Sem título”, em Manchete, 5 de julho de 1952.
} 
Esse exemplo retrata a popularidade e aceitação da estética estadunidense quando o assunto era beleza feminina. Não era incomum a associação, em campanhas publicitárias de produtos de beleza, do belo com limpeza e jovialidade. Modernidade, atualidade, juventude e beleza eram valores ligados ao paradigma estético estadunidense.

As estrelas de Hollywood, como Elisabeth Taylor, Joan Crowford e muitas outras, seriam a inspiração para muitas mulheres na procura de produtos que as tornassem mais belas e na composição dos modelitos que iriam vestir.

Sr. Eduardo Alijó, quais são as preferências das mulheres brasileiras da classe média em seus estabelecimentos de modas? -A fim de melhor responder à vossa pergunta, pedimos permissão para tecermos as seguintes considerações: A mulher brasileira, especialmente a carioca, representada na sua maioria pela classe média, tem a verdadeira concepção de elegância, pois está a par de tudo que surge de novo no domínio da moda e tem o seu sentido prático para a escolha do seu vestuário, preferindo as linhas simples dos vestidos e costumes, porém, com exigências em relação a pequenos detalhes que completam o seu vestuário e a prática nos ensinou ser o mais difícil. Temos observado que, sendo graciosa no andar, não encontra dificuldade de completar sua elegância natural, comprando vestidos prontos, sem qualquer prova, mediante apenas uma pequena retificação, o que lhe permite comprar por preço mais acessível o seu vestuário. Acompanhando a tendência elegante da mulher brasileira, nos esforçamos na apresentação constante de vestidos e costumes de linha moderna, baseados nos modelos europeus e americanos, aos quais damos um cunho todo nosso, tudo dentro de uma elegância sóbria que agrada sempre a classe média $[\ldots]^{25}$.

A reportagem demonstra como a mulher brasileira possuía a verdadeira concepção de elegância e beleza, com base nos modelos americanos, mais sóbrios e práticos, como a vida naquele país pretendia ser. Mas a questão não para aí, havia ainda um novo hábito: a compra dos vestidos prontos.

A chegada das grandes lojas de departamentos, adequadas ao momento vivido de mais rapidez e praticidade na vida cotidiana, trazia consigo não apenas outro ideal de vestir, com peças pré-moldadas segundo padrões industriais, mas também novas relações de trabalho, perdendo, as antigas costurarias particulares, espaço para as grandes marcas que valorizavam o trabalho serializado, e, principalmente, novos hábitos de consumo. Os brasileiros entravam efetivamente no modelo de vida ocidental.

Para além da inspiração estética, os Estados Unidos também eram um paradigma tecnológico. São comuns as referências ao desenvolvimento tecnológico estadunidense, especialmente no que diz respeito ao programa espacial daquele país, que, no mundo ocidental, se tornou um exemplo de avanço técnico-científico. Enquanto isso, os passos soviéticos eram pouco comentados e muitas vezes interpretados de forma a colocá-los de forma negativa.

25 “O Brasil Pergunta", em Manchete, 31 de maio de 1952. Grifos meus. 
Para além das fronteiras nacionais: imagens do americanismo como modelo de vida...

É o que vemos na matéria "O Sol é o Limite", de Manchete, em 21 de março de 1959. A reportagem maciçamente ilustrada, narra o lançamento do satélite Juno II.

Pouco antes da meia noite, a enorme torre começou a mover-se, deixando livre o foguete de sessenta toneladas. A contagem terminou na madrugada do dia 3: a cauda de fogo foi crescendo, à medida que Juno II ganhava altura, levando no nariz um satélite dourado de seis quilos. No Cabo Canaveral, funcionários americanos esperaram as duas horas necessárias, para anunciar o êxito da prova: os EUA iam ter seu planeta artificial ${ }^{26}$.

A matéria continua em tom de contentamento e destaque ao sucesso estadunidense. $\mathrm{Na}$ página seguinte, informa: "O esforço americano em direção a lua, feito com liberdade quase absoluta de informações, sempre pareceu maior que o soviético, por uma razão muito simples: somente um foguete lunar bem sucedido devolveria aos Estados Unidos o prestígio perdido com o sucesso russo no lançamento dos satélites artificiais". (Grifos meus). Depois passa a narrar os passos do programa espacial estadunidense em seus sucessos e fracassos, sempre em comparação com o lado soviético. Ao final, a reportagem conclui: "Com o Pioneiro IV, os Estados Unidos completaram um total de nove satélites e duas sondagens lunares. A estatística é possível porque os sucessos e fracassos puderam ser documentados livremente" Apesar de anunciar um aparente sucesso russo, o periódico fazia questão de enaltecer a liberdade estadunidense, que não esconde informações. Ou seja, o sucesso só se deu após alguns fracassos, como é comum na livre iniciativa, onde o erro também deve ser valorizado como um passo necessário para se chegar ao objetivo final. Isso tornava a vitória estadunidense maior que a do seu rival.

Em suma, o Brasil entrava definitivamente na esteira do modelo ocidental. As noções de beleza e moda seguiam os ditames da estética e da indústria estadunidense, propaladas pelos meios de comunicação e diversão de massa, como o cinema e, especialmente, a televisão. Também vinha do Norte os modos de consumir e, consequentemente, de viver o cotidiano, uma vez que esta era uma prática definidora dos modos de experienciar na contemporaneidade. Os produtos que entravam nas casas traziam com eles valores culturais, ideais estéticos, formas de sentir, ver, sonhar, enfim, ser e estar no mundo.

Tudo isso enquadrava os limites de ação e também imaginação dentro da lógica bipolar. As peças publicitárias, as revistas, o cinema, a televisão, enfim, os mais diversos meios de comunicação lembravam a todo momento as vantagens do mundo ocidental diante dos horrores do outro lado do mundo. Não havia debate, a coisa já estava ali, dada como verdade inquestionável. Pensar diferente era estar do outro lado, era ser uma forma de replicante, espécime banida da terra e que deveria ser temida e combatida a qualquer custo, para fazer uma analogia com os androides de Ridley Scott em Blade Runner.

\footnotetext{
${ }^{26}$ Manchete, 21 de março de 1959.
} 
Com a renúncia de Jânio Quadros e a chegada de João Goulart à presidência da república, figura há muito identificada com as questões trabalhistas e ligado aos ideais da esquerda urbana brasileira, essa situação se evidencia. Eram os anos 60, a Revolução Cubana havia direcionado um importante porto de influência estadunidense nas Américas para as hostes soviéticas. Os medos e ânimos se exaltaram. Temia-se uma nova Cuba em solo nacional. E também no campo político os interesses brasileiros e estadunidenses convergiam. É nesse contexto que a Escola Superior de Guerra, criada em 1949 seguindo o modelo do National War College estadunidense, passou a ter um diálogo mais direto com a diplomacia estadunidense, da mesma forma que o Instituto Brasileiro de Ação Democrática (IBAD), fundado em 1959 com vistas a combater o comunismo no país e o Instituto de Pesquisas e Estudos Sociais (IPES), fundado em 1961, com objetivos similares. Essas instituições formavam um grande complexo de divulgação dos ideais ocidentais, especialmente aqueles inspirados no americanismo, e de cerco ao comunismo, através, principalmente, de propagandas.

Assim, a partir do início dos anos 60, como produto dessa ofensiva dos grupos econômicos dominantes, as revistas passaram a veicular diariamente uma quantidade espantosa de artigos e matérias exortando o comunismo, e fazendo a apologia das liberdades individuais e da iniciativa privada. No centro de tudo isso estava a palavra liberdade $e^{27}$.

Aliados aos valores de liberdade, democracia e individualidade, outro princípio intimamente relacionado ao americanismo que seria enaltecido era o da livre iniciativa. Valorizava-se o esforço pessoal e o trabalho na busca do sucesso e felicidade na vida, que, se não se confundiam, ao menos dependiam essencialmente de uma vida financeira estável que garantisse a possibilidade de escolha de todos os bens necessários a uma vida confortável. É essa a ideia da peça publicitária paga pelos Diários Associados e divulgada na O Cruzeiro em maio de 1962.

Já no cabeçalho um chamado: "Defenda o seu direito de progredir: defenda a livre iniciativa". Logo abaixo, a imagem de um homem a procura de emprego. O ângulo da fotografia é estrategicamente escolhido para fazer o leitor identificar-se com a mensagem, sentindo-se dentro da imagem; era como se fosse ele próprio a procura de emprego. Por fim, um recurso cada vez menos comum na publicidade dentro do regime visual contemporâneo: o uso de textos longos. Mas aqui ela justificava-se: utilizava-se um recurso tradicional para convencer o leitor da importância de um valor também tradicional: o trabalho. Assim, argumenta-se que o trabalhador, no regime de livre iniciativa, tem sempre "[...] o caminho livre [...] para atingir honrosamente às posições a que tem direito". Nesse tipo de sociedade, a liberdade é plena, até mesmo para "escolher o patrão, ou o emprego que melhor convier ao seu desejo de progredir". As quatro liberdades básicas são exaltadas ao fim "a de trabalhar, a de produzir, a de vender e a de comprar". A alusão é direta ao imaginário do self made man, arraigado na sociedade estadunidense, ou seja, aquele indivíduo que, por esforço próprio e dedicação intensiva ao trabalho, conseguiu erguer-se na vida e superar todos os obstáculos encontrados.

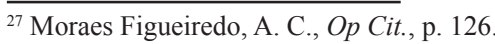


Para além das fronteiras nacionais: imagens do americanismo como modelo de vida...

Imagem 4. Logo abaixo, a imagem de um homem a procura de emprego.

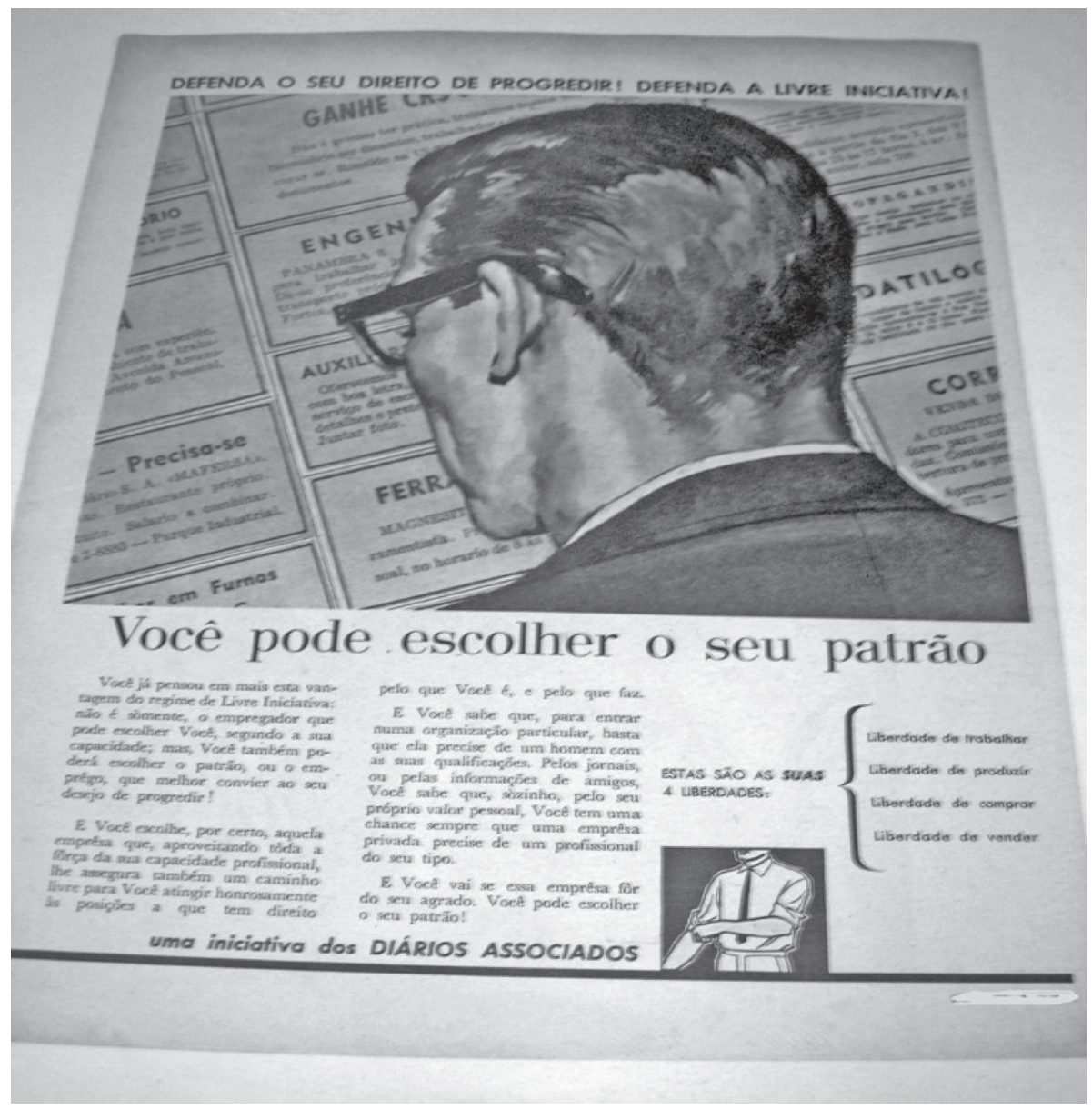

Fonte: O Cruzeiro, 5 de maio de 1962.

Todos esses princípios, portanto, estariam embutidos das mais diversas formas no cotidiano do cidadão comum no Brasil. Fosse através dos produtos que consumia, das revistas que lia, dos programas de televisão ou filmes aos quais assistia, eles estariam lá, como um uníssono a relembrar o caminho das "escolhas corretas". No mundo comunista, nada disso se fazia presente.

É o que vemos em outra peça publicitária do mesmo anunciante, Os Diários Associados, veiculada em O Cruzeiro de 27 de outubro de 1962. Aí está presente um importante retrato da visão do mundo desejável, livre. A propaganda de página inteira traz em letras capitais e ocupando metade da folha o dizer: o que você diz sobre isto? Logo abaixo, em fonte um pouco menor: o automóvel, a liberdade e o bem-estar. Seguindo a página em fonte pequena e em três colunas, o texto reproduzido abaixo. 
Não há nenhuma utilidade ou instrumento de conforto criado pelo homem que exprima tanto o nível de vida atingido pelo indivíduo como o automóvel. Pois, o "carro da família" é a primeira coisa que ele compra, logo que seu nível de salário ou rendimento já lhe permitiu comprar a geladeira, o rádio, a eletrola, o aparelho de TV e outros aparelhos domésticos. Todos sabem que os comunistas, invertendo a ordem humana das coisas, procuram dizer que o mais importante não é a liberdade, mas o bem-estar econômico do cidadão. Pois bem, estes números sobre a existência de automóveis no mundo provam de modo claro e irrespondível que os povos dos países comunistas, além de perderem o bem supremo da liberdade, vivem nas mais atrasadas condições de conforto e nível de vida ${ }^{28}$.

Após ter chamado a atenção do leitor/expectador, a página seguinte trazia dados numéricos como que para corroborar de forma inquestionável o que se afirmava. A organização do texto também merece destaque: ela começa com letras menores e vai aumentando para, finalmente, destacar, de forma segmentada, o texto principal, que trata sobre o Brasil.

7 milhões de venezuelanos têm 7 vezes mais carros que os 700 milhões de "felizes" chineses e comunistas.

Os 4 milhões de bolivianos (considerados entre os povos mais pobres do mundo livre) têm mais automóveis (13.000) que os 14 milhões de habitantes da Romênia, uma das "estrelas" do mundo comunista e onde há apenas 10.000 carros.

1 carro para cada 1.000 habitantes do mundo comunista.

1 carro para cada 135 habitantes da Alemanha Comunista.

1 carro para cada 11 habitantes da Alemanha Ocidental (Livre)

Além de serem livres, os 72 milhões de brasileiros já têm tantos automóveis (650.000) quanto os 220 milhões de habitantes da Rússia ("Paraíso") comunista -e têm 20 vezes mais automóveis que os "felizes" 700 milhões de chineses vermelhos ${ }^{29}$.

Mais uma vez o discurso é claro, sem entrelinhas: é possível se medir a felicidade a partir do que se tem e o padrão de vida ocidental proporciona maior felicidade que o seu rival, visto como negativo e limitador das liberdades. O uso da ironia é constante, referindo-se aos países socialistas com adjetivações positivas entre aspas, como que a relativizar a verdade dessas afirmações. Também faz-se questão de diferenciar as Alemanhas, não a socialista e a liberal, mas a comunista e a livre.

Por meio dessa estratégia, os textos das revistas confundiam de tal forma os termos liberdade, democracia e capitalismo de um lado, e escravidão, totalitarismo e comunismo de outro, que criavam verdadeira incompatibilidade entre os dois conjuntos, a ponto de eliminar qualquer possibilidade de se imaginar que um dia pudesse existir uma sociedade que fosse ao mesmo tempo democrática e não capitalista. Tanto é assim que se tornou hábito designar pela expressão "mundo livre" os países capitalistas e, por consequência, associar o regime comunista à ideia de ausência de liberdade ${ }^{30}$.

\footnotetext{
${ }^{28}$ O Cruzeiro, 27 de outubro de 1962.

${ }^{29}$ Ibid.

${ }^{30}$ Figueiredo, A. C. Moraes, Op Cit., p. 129.
} 
Para além das fronteiras nacionais: imagens do americanismo como modelo de vida...

A liberdade era o valor máximo da vida no ocidente. E não era à toa: esse era (e continua sendo!) o valor supremo, mito fundacional da nação estadunidense. Desde sua independência, todos os esforços, todas as lutas tinham por princípio a defesa da mesma. Esse é o primeiro princípio que une as 13 colônias em torno do mesmo objetivo, como já atestava a primeira bandeira representativa dessa união: um tecido quadrado com a palavra Liberty ao centro ${ }^{31}$. Portanto, tolher a liberdade é tolher a razão da própria existência. Para os Estados Unidos e para todo o Ocidente. E, especialmente na era da bipolaridade, nada melhor para representar esse valor supremo que a liberdade de consumir. Suprimir isso era também suprimir a felicidade, a alegria. Os produtos trazem (ou prometem trazer) essa satisfação. Consumir era uma ação de cidadania e de querer bem, como faziam crer as propagandas que incentivavam a compra de produtos para serem dados como presente.

Por fim, retomemos a imagem 3. Tomei-a, aqui, como representação coesa da leitura hegemônica do americanismo no Brasil, pois, a meu ver, ela consegue englobar todos os arquétipos apresentados e discutidos aqui: a liberdade em suas múltiplas formas e expressões, o paradigma técnico-científico, a universalidade do ocidente, a cultura de consumo e todas as suas transformações sociais e subjetivas-vale lembrar: a modelo está vestida em um biquíni da moda e sapatos altos e elegantes. Seu sorriso traz a alegria e o bem-estar que, na sociedade de consumo, os produtos prometem proporcionar. Todavia, o que torna a imagem ainda mais significativa do período é a sua visualidade: é o olhar fixo da atriz em um horizonte ao alto, talvez distante, mas seguro, tranquilizador. Um futuro dentro do espectro presentista. É um olhar que mira o céu, ou melhor, um norte, um exemplo a seguir, algo incontestável, uma certeza. $\mathrm{O}$ foguete nas mãos indica essa direção, assim como o conjunto visual da fotografia: o American way of life. Daí a serenidade da expressão e a alegria e confiança do sorriso. O Brasil havia descoberto uma estrela brilhante pela qual poderia se guiar.

A proposta deste artigo foi discutir como os valores americanistas se fizeram presentes na construção de um paradigma cultural ocidental, ou, na formação de uma Comunidade Imaginada chamada de Ocidente. Melhor dizendo, como a ideia de Ocidente passou a ser agenciada para referir-se a uma comunidade imaginada baseada nos valores americanistas no Brasil a partir do Pós-Guerra. Isso se fez, também, a partir de uma subjetivação imagética, ou seja, a construção de uma visualidade, dado que acredito ter demonstrado, ainda que de forma inicial, nos limites deste artigo.

\section{Fontes}

\section{Fontes Primárias}

\section{Periódicos}

Revista O Cruzeiro (Edições de 05/05/1962 e 27/10/1962)

\footnotetext{
${ }^{31}$ A liberdade é um dos valores fundacionais da nação estadunidense. Existem diversas discussões a respeito da transformação desse valor em um mito nacional que persiste ao longo de toda a história dos Estados Unidos da América. Para mais a esse respeito: Hackett Fischer, D., Op Cit.
} 
Revista Manchete (Todas as edições de Maio, Junho e Julho de 1952 e a Edição de 21 de março de 1959).

\section{Fontes Secundárias}

\section{Livros}

Debord, Guy. A Sociedade do Espetáculo. Rio de Janeiro: Contraponto, 1997.

Fischer, David Hackett. Liberty and Freedom. A visual history of America's Founding Ideas. Oxford University Press, 2005.

Glickman, Lawrence B (ed). Consumer society in American history: A Reader. Cornell University Press, 1999.

Grazia, Victoria de. Irresistible empire: America's advance through $20^{\text {th }}$ century Europe. Cambridge, Massachusetts: Harvard University Press, 2005.

Holloway, David e Beck, John. American Visual Cultures. London, New York: Continuum, 2005.

Roche, Daniel. História das Coisas Banais: o nascimento do consumo nas sociedades do século XVII ao XIX. Rio de Janeiro: Rocco, 2000.

Saunders, Frances Stonor. The Cultural Cold War: The CIA and the world of arts and letters. New York: The New Press, 2000.

Sturken, Marita e Cartwright, Lisa. The practices of looking. An introduction to Visual Culture. Oxford University Press, 2001.

Tota, Antônio Pedro. Imperialismo Sedutor: a americanização do Brasil na época da Segunda Guerra. São Paulo: Cia das Letras, 2000.

\section{Capítulo de Livro}

Camargo Moraes, Anna Cristina. "A Liberdade é uma calça velha azul e desbotada", em Publicidade, Cultura de Consumo e Comportamento Político no Brasil (19541964). São Paulo: Hucitec, 1998. 